\title{
Soteriologiczny paradygmat wadżrajany
}

\author{
Marek SZYMAŃSKI*
}

\begin{abstract}
The soteriological paradigm of Vajrayanna: The purpose of the paper is to determine the distinctive soteriological paradigm of Tantric Buddhism. The view of Shinichi Tsuda is critically analyzed. The belief that symbols of Buddhahood are essential to achieve Buddhahood appears specific for Vajrayāna. Relevant manipulation of the symbols can be ritual or/and imaginary. Followers are convinced that the manipulation enables them to achieve the final religious goal, not only the intermediate steps. They also believe they can activate and control the processes that are not dependent on enlightened beings' good will. However, such a position need not exclude the appreciation of moral and cognitive virtues. Some aspects and variants of the Vajrayāna soteriological paradigm are discussed to avoid any misinterpretation.
\end{abstract}

\section{KEYWORDS}

symbols of Buddhahood; symbol manipulation (ritual or imaginative); moral and cognitive virtues; deity yoga; internalization of a ritual

* Dr hab., adiunkt, Zakład Religioznawstwa i Filozofii Wschodu, Instytut Filozofii, Uniwersytet Marii Curie-Skłodowskiej w Lublinie. E-mail: marek.szymanski@poczta.umcs.lublin.pl. 


\section{WSTĘP}

Zgodnie z powszechnym przekonaniem, różnic między wadżrajaną a starszym buddyzmem należy szukać przede wszystkim w dziedzinie praktyki religijnej. Tantryczny buddyzm jest jednak formacją, która cechuje się wysokim stopniem zróżnicowania w zakresie zachowań rytualnych i medytacyjnych. Co więcej, różne techniki uważane za typowe dla wadżrajany posiadają odpowiedniki w starszym buddyzmie. Nic dziwnego, że definicja wadżrajany pozostaje kwestią sporną. W przekonaniu piszącego te słowa tantryczny buddyzm charakteryzuje się akceptacją swoistego paradygmatu soteriologicznego, który wyraźnie odbiega od podejścia właściwego dla innych buddyjskich tradycji. Zgodnie z tym przekonaniem, odmienności wadżrajany od pozostałych postaci buddyzmu nie da się sprowadzić do historycznie uwarunkowanych różnic w doborze obiektów kultu oraz w przebiegu obrzędów i praktyk medytacyjnych. Wyjątkowa ranga mantr, mudr, mandali (i innych wizerunków) oraz technik wizualizacji w praktyce wadżrajany zdaje się świadczyć o czymś więcej niż przywiązanie do określonych akcesoriów i motywów. W owej randze można widzieć symptom konsekwentnego stosowania szczególnej metody, która ma umożliwiać realizację stanu buddy (osiągnięcie głównego religijnego celu). Oryginalność tej metody jest związana $\mathrm{z}$ akceptacją założeń, które nie są uznawane przez przedstawicieli innych buddyjskich tradycji. Identyfikacja tych założeń pozwala sformułować taką definicję wadżrajany, która uwzględnia cechy swoiste definiowanego zjawiska i charakteryzuje się adekwatnością.

Badania nad soteriologicznym paradygmatem wadżrajany prowadził Shinichi Tsuda. Analiza wyników jego pracy stanowi punkt wyjścia niniejszego tekstu ${ }^{1}$. Zaproponowano w nim zasadniczą korektę owych wyników z uwzględnieniem rezultatów nowszych badań. Zdaniem japońskiego badacza o oryginalności wadżrajany decyduje akceptacja modelu soteriologicznego obcego wcześniejszemu buddyzmowi. Tsuda nazywał ten model „tantrycznym”. Przyjmował, że akceptacja tantrycznego paradygmatu w obrębie indyjskiego buddyzmu miała zróżnicowany charakter. Na podstawie analizy buddyjskich tantr Tsuda wyróżnił trzy przypadki. W pierwszym tantryczny model był akceptowany w sposób otwarty i konsekwentny. Drugą sytuację można sprowadzić do wywierania przez tantryczny model wpływu na religijną praktykę wbrew deklarowanej akceptacji modelu soteriologicznego mahajany. W przypadku trzecim próbowano uzgodnić dwa modele. Zdaniem Tsudy, każda tego rodzaju próba była skazana na porażkę ze względu na zasadniczą przeciwstawność modeli. $Z$ powyższych przekonań wynika, że każda z tradycji zaliczanych do tantrycznego buddyzmu, która

\footnotetext{
${ }^{1}$ Punktem odniesienia tej analizy jest artykuł Shinichiego Tsudy zatytułowany $A$ critical Tantrism. Ukazat się on w: Memoirs of the Research Department of the Toyo Bunko, 36 (1978), s. 167-231. Korzystam z jego przedruku (Tsuda, 2005). Wszystkie odnośniki dotyczą tej edycji.
} 
obficie czerpie z dokonań mahajany i której nie sposób sprowadzić do pierwszego z wyróżnionych przypadków, naznaczona jest wewnętrzną niespójnością. Sposób rozumienia przez Tsudę modelu tantrycznego każe mu tak traktować przytłaczającą większość tradycji indyjskiej wadżrajany. Tym samym owe tradycje są postrzegane jako naznaczone zasadniczą i dyskwalifikującą je ułomnością. Uświadomienie sobie tych konsekwencji rodzi nieufność względem interpretacji Tsudy. Analiza pozwala zaś wykazać jej błędność.

Ostatnia część tekstu stanowi próbę zdefiniowania soteriologicznego modelu, który jest wewnętrznie spójny i charakterystyczny dla całej wadżrajany. Próbę tę należy traktować jako propozycję, która wymaga dalszej weryfikacji poprzez konfrontację z zachowanymi tekstami i materiałem empirycznym. W niniejszym tekście wyróżniono podstawowe warianty tego modelu.

\section{STANOWISKO TSUDY}

Tsuda przeciwstawiał sobie dwa soteriologiczne paradygmaty: model mahajany i model tantryczny. Rozumiat je w następujący sposób. Model mahajany zdominował sposób myślenia indyjskich buddystów w okresie poprzedzającym rozwój wadżrajany. Fundamentem tego modelu soteriologicznego jest przekonanie o konieczności gruntownego przekształcenia własnego umysłu. Proces ten tradycyjnie opisywano jako oczyszczanie umysłu, tj. jako postępującą kontrolę czynników psychicznych uznawanych za niepożądane (aż do wykluczenia możliwości ich powstania). Pozytywnie rzecz biorąc, przekształcanie umysłu ma dwa aspekty: wytrwałe gromadzenie karmicznych zasług oraz zdobywanie intelektualnych i moralnych cnót (należy osiągnąć doskonałość w zakresie mądrości i miłosierdzia). Soteriologiczny model mahajany jest osadzony w kontekście wyobrażeń o istnieniu kosmicznej wspólnoty wszystkich świadomych istot. Bardzo ważną rolę odgrywa tu gotowość niesienia pomocy wszystkim cierpiącym. W perspektywie rozważań Tsudy sprawą kluczową jest jednak to, że w mahajanie proces duchowego rozwoju jest uważany za wielostopniowy, wręcz niewyobrażalnie długotrwały (obejmujący ogromną liczbę cykli życiowych) i uciążliwy (Tsuda, 2005: 418-420).

W modelu tantrycznym sposobem doskonalenia własnej osoby jest rytualna manipulacja symbolami. U podstaw takiego podejścia leży przekonanie o istnieniu szczególnego związku między symbolem religijnym oraz jego korelatem. Przyjmuje się, że symbol realnie uobecnia swój korelat. Należy włączyć adepta w obręb oddziaływania symboli tego, co doskonałe, bowiem tym samym zostaje on poddany bezpośredniemu wpływowi rzeczywistości wzorcowej. Ma to prowadzić do zbawczej przemiany rozumianej jako integracja z rzeczywistością doskonałą dzięki upodobnieniu się do niej. Na takiej właśnie zasadzie mają wywierać zbawienny wpływ mantry, mudry, mandale i inne symbole stanu buddy. Przeniesienie manipulacji symbolami na płaszczyznę wyobraźni 
w zasadzie niczego w omówionym podejściu nie zmienia. W tantrycznym buddyzmie doskonała rzeczywistość jest personifikowana w postaci określonych istot oświeconych. Manipulacja symbolami rozpatrywana w tej perspektywie służy uobecnieniu określonych istot oświeconych oraz osiągnięciu stanu identyczności z nimi (Tsuda, 2005: 452-453).

Zwolennicy modelu tantrycznego wierzą w możliwość szybkiej przemiany zbawczej. Tsuda za charakterystyczne dla „logiki tantryzmu” uznawał przekonanie, że przekształcenie organizmu, które prowadzi do zjednoczenia z doskonałą rzeczywistością, jest względnie łatwe (Tsuda, 2005: 419, 449). Jednym z najważniejszych punktów odniesienia w jego rozważaniach jest tantra Sarva-tathāgata-tattva-samgraha, w której jakoby „od indywiduum jest wymagane w zasadzie tylko użyczenie ust do recytacji mantr, użyczenie umysłu do wyobrażania sobie symbolicznych obiektów oraz użyczenie rąk do odpowiedniego układania palców" (Tsuda, 2005: 452)².

W modelu tantrycznym przyjmuje się, że w sytuacji rytualnej sam adept pełni funkcję symbolu, stając się obiektem, poprzez który (w którym) uobecnia się to, co doskonałe. Chodzi o to, by dzięki praktyce religijnej taki związek z wzorcową rzeczywistością pogłębić do stanu permanentnej identyczności. Tsuda wyróżnił dwa warianty „tantrycznej jogi” rozumianej jako proces prowadzący do tego celu. W ramach pierwszego przyjmowano, że między organizmem psychofizycznym a wzorcową rzeczywistością w pewnych aspektach występuje podobieństwo. Przy użyciu rozmaitych symboli dążono do wywołania efektu ekstrapolacji tego podobieństwa do poziomu ścisłej odpowiedniości. Adept ma uzyskiwać w ten sposób wszelkie własności tego, co doskonałe, co czyni z niego buddę. W ramach drugiego podejścia przyjmowano, że występuje strukturalna odpowiedniość między organizmem adepta a rzeczywistością wzorcową. Ten stan rzeczy nie gwarantuje soteriologicznego sukcesu, ale otwiera możliwość harmonizowania kolejnych form aktywności własnego organizmu z rzeczywistością wzorcową. Różne wyobrażenia dotyczące strukturalnej odpowiedniości rozpatrywanych dziedzin leżą u podstaw rozmaitych technik służących kształtowaniu sposobu, w jaki funkcjonuje organizm adepta. Tego rodzaju techniki również opierają się na manipulacji symbolami i są oceniane jako łatwe w porównaniu z tradycyjną ścieżką bodhisattwy (Tsuda, 2005: 422, 449, 451).

Tsuda sądzit, że model soteriologiczny mahajany i model tantryczny są fundamentalnie przeciwstawne. Zainteresowanie tantrycznym modelem soteriologicznym w buddyzmie pojawić się miało jako reakcja na ekstremizm modelu mahajany w sytuacji szybko postępującego upadku tradycyjnych postaci buddyjskiej religii (Tsuda, 2005: 418-419). Tsuda patrzył na dzieje indyjskiej wadżrajany jako na ścieranie się tych modeli. Przypisywał im (explicite albo implicite) następujące cechy przeciwstawne:

\footnotetext{
${ }^{2}$ Cytat w thumaczeniu autora.
} 
1. w modelu mahajany funkcja zbawcza jest przyznawana czynnikom wewnętrznym, tj. odpowiednim stanom własnego umysłu (z ewentualnym wsparciem czynników zewnętrznych), zaś w modelu tantrycznym rola ta przypada czynnikom zewnętrznym, skutecznym jakoby samoczynnie (symbolom stanu buddy rozumianym jako rzeczywistość sakramentalna);

2. praktyka religijna $\mathrm{w}$ modelu mahajany polega na doskonaleniu umystu $\mathrm{w}$ aspekcie poznawczym i moralnym, zaś praktyka w modelu tantrycznym to mechaniczna manipulacja symbolami (w rzeczywistości albo w wyobraźni);

3. praktyka zgodna z modelem mahajany jest żmudna i długotrwała, zaś praktyka tantryczna jest względnie łatwa i prowadzi do celu stosunkowo szybko;

4. model soteriologiczny Wielkiego Wozu jest elitarny, zaś model tantryczny ma charakter egalitarny, bowiem zdecydowana większość wyznawców mahajany uważa, że w przewidywalnym czasie stan buddy nie będzie się znajdować w ich zasięgu (podobnie jak wysokie, chociaż niższe od niego, poziomy duchowego rozwoju), natomiast zwolennicy drugiego modelu widzą w owym stanie nieodległy rezultat własnej praktyki religijnej.

Wskazane kontrasty czynią interpretację Tsudy wysoce klarowną i na pierwszy rzut oka przekonującą. Sytuuje ona wyróżnione modele soteriologiczne po dwóch stronach barykady w odniesieniu do spraw tradycyjnie uznawanych w buddyzmie za pryncypialne. Przyporządkowuje bowiem owym modelom przeciwstawne oceny roli poznania i moralności. W tej sytuacji każdy, kto sądzi, że buddyzm wymaga od swych wyznawców dążenia do moralnej doskonałości i mądrości, musi uznać, że akceptacja tantrycznego modelu soteriologicznego jest stanowiskiem heretyckim (Tsuda, 2005: 429-431). Co więcej, akceptacja modelu tantrycznego jest przez Tsudę przedstawiana jako obiektywne zagrożenie rozwojem nihilizmu, bowiem przeświadczenie o łatwości osiągnięcia stanu buddy godzi w przekonanie o konieczności podporządkowania się normom postępowania (Tsuda, 2005: 454).

Zdaniem Tsudy akceptacja tantrycznego modelu soteriologicznego może mieć różny charakter:

1. może być otwarta i konsekwentna (jak w tantrze Sarva-tathāgata-tattva-samgraba);

2. może mieć miejsce w kontekstach rytualnych wbrew deklarowanej akceptacji modelu mahajany (jak w tekście znanym jako Vairocana-abhisambodhi-sūtra);

3. może być osłabiana przez obecność wierzeń lub praktyk, które są niezgodne z uznawanym modelem (jak w Tantrze Hewadżry czy Tantrze powstania najwyższej przyjemności) ${ }^{3}$.

${ }^{3}$ Odstępstwa od modelu tantrycznego we wskazanych tekstach polegały jakoby na (odpowiednio) przyznaniu istotnej roli mądrości (rozumianej jako niezależna od manipulacji 
W przypadku tych postaci buddyzmu, które odwołują się do modelu tantrycznego, mamy więc do czynienia albo z otwartą zdradą buddyjskich pryncypiów i zjawiskiem społecznie niebezpiecznym (przypadek 1), albo z występowaniem sprzeczności między istotnymi elementami światopoglądu (przypadki 2 i 3). Japoński badacz przedstawił schemat rozwoju indyjskiej wadżrajany, w którym kolejno powstające jej postaci stanowią próbę usunięcia wewnętrznych napięć charakterystycznych dla postaci wcześniejszych.

\section{KRYTYKA STANOWISKA TSUDY}

Interpretacja Tsudy ma charakter normatywny i, jak się wydaje, aprioryczny. Jest uzasadniana $\mathrm{w}$ sposób, którego trudno nie uznać za tendencyjny. Wedemeyer widzi w niej przejaw buddyjskiej teologii (Wedemeyer, 2013: 220, przyp. 56). Główne zastrzeżenie dotyczy traktowania dychotomicznego schematu jako ogólnego modelu interpretacyjnego. Rezultatem takiego podejścia jest traktowanie wszystkich tantrycznych tradycji buddyjskich, w których zbawcza przemiana jest rozumiana w sposób niedający się przyporządkować jednemu z dwóch wyróżnionych wzorców soteriologicznych, jako prób łączenia wody z ogniem. Wydaje się to bezzasadne. Tsuda zdaje się ignorować metodologiczny postulat poszukiwania w pierwszej kolejności takiej interpretacji tekstu, która pozwala uznać spójność jego treści. Można ten problem ująć inaczej. Tsuda uznawał za charakterystyczne dla modelu tantrycznego przekonanie, że manipulacja symbolami pełni rolę warunku koniecznego i wystarczającego osiągnięcia stanu buddy. Przyjmował również, że odrzucenie tego stanowiska na rzecz przyznania manipulacji symbolami funkcji koniecznego, ale niewystarczającego warunku zbawczej przemiany, w nieunikniony sposób generuje systemowe antynomie. Rzecz w tym, że pierwsze założenie ma charakter arbitralny, drugie zaś wydaje się fałszywe. Ich odrzucenie pozwala traktować te postaci wadżrajany, które nie mieszczą się $\mathrm{w}$ dychotomicznym schemacie Tsudy (a takie właśnie zdają się stanowić zdecydowaną większość), jako zasadniczo spójne tradycje tantryczne, a nie jako zjawiska hybrydalne. Przyjrzyjmy się wyżej wskazanym parom cech, które Tsuda przypisał wyróżnionym modelom soteriologicznym, w perspektywie krytyki założeń przyjmowanych przez japońskiego badacza.

Ad. 1. Przyznanie rytualnej manipulacji symbolami statusu czynnika niezbędnego $\mathrm{w}$ praktyce religijnej nie musi iść $\mathrm{w}$ parze $\mathrm{z}$ kwestionowaniem zbawczej roli określonych stanów umysłu adepta. Wyznawcy wadżrajany zwykle przyjmują, że osiągnięcie stanu buddy wymaga zarówno takiej

symbolami) oraz na uwzględnieniu wysoce uciążliwych pielgrzymek (Tsuda, 2005: 460-461, 472-475). Tego rodzaju odstępstwa miałyby stanowić rezultat braku zaufania do autentycznej wartości stanów osiąganych bez wysiłku lub rezultat poczucia zagrożenia rozwojem nihilizmu. 
manipulacji, jak i wystąpienia odpowiednich stanów umysłowych. Taki punkt widzenia jest powszechny już w buddyjskich tantrach. Nie może to zaskakiwać, zważywszy, że manipulacja symbolami z konieczności posiada aspekt psychiczny.

Zalecanym w tantrach obrzędom, w których przekraczano rozmaite normy zachowania, często towarzyszyły intensywne emocje (między innymi lęk czy obrzydzenie). Trudno nie zgodzić się z Tsudą, że tego rodzaju stany psychiczne ułatwiały przekonanie adepta o dogłębności i realnym charakterze dokonującej się w nim przemiany. Wykorzystanie symboli, które wzbudzają silne emocje, wiązało się jednak z przyznaniem psychicznemu wymiarowi rytualnej praktyki statusu czynnika istotnego czy wręcz kluczowego. Ważną rolę wśród tego rodzaju stanów odgrywała ekstaza będąca zwieńczeniem rytuałów seksualnych. Nie ma powodów, by twierdzić, że uznawanie manipulacji symbolami za niezbędną do osiągnięcia stanu buddy musi pozostawać w konflikcie z przekonaniem o zbawczej roli określonych stanów umysłu adepta.

Ad 2. Dokonana przez Tsudę wykładnia opowieści z tantry Sarva-tathāgata-tattva-samgraba jako świadectwa akceptacji modelu, w którym soteriologiczna rola cnót mahajany została całkowicie zignorowana, jest problematyczna. W szczególnych kwalifikacjach Sarwarthasiddhiego (jego cnotach bodhisattwy) widzieć można (zamiast faktu bez soteriologicznego znaczenia) warunek natychmiastowej skuteczności zastosowanych mantr i wizualizacji. Poza tym sam Tsuda wydaje się przyznawać, że dzięki mantrom i wizualizacjom w Sarwarthasiddhim zachodzi przemiana o charakterze kognitywnym ${ }^{4}$. Można mnożyć czerpane z tantr przykłady na to, że zmianę sposobu funkcjonowania umysłu uważano za kluczowy aspekt zbawczej przemiany adepta. Manipulacja symbolami ma prowadzić do wglądu w naturę rzeczywistości, co pozostaje w zgodzie $\mathrm{z}$ dążeniem do uzyskania cnoty mądrości w mahajanie. Ekstazę, która wieńczy seksualne rytuały, odróżniano od orgazmu profanów między innymi poprzez przypisanie jej funkcji kognitywnej. W takiej ekstazie ujawniać się ma jednorodna natura rzeczywistości przeciwstawianej wszelkim schematom pojęcio$\mathrm{wym}^{5}$. Wedemeyer ma rację, twierdząc, że nowatorskie techniki soteriologiczne zalecane $\mathrm{w}$ tantrach były zintegrowane $\mathrm{z}$ tradycyjnym buddyjskim światopoglądem. Badacz ten wykazał, że przyznanie w wadżrajanie funkcji zbawczej rytualnym działaniom, które naruszają moralne i obyczajowe tabu, było związane z przypisaniem takim zachowaniom funkcji gnozotwórczej (Wedemeyer, 2013: 121-125, 144-148) .

${ }^{4}$ Zastosowana przez niego metoda pozwala mu osiągnąć „prawdę wszystkich tathagatów”, tj. „najwyższą prawdę” (Tsuda, 2005: 446).

${ }^{5}$ Por. rekonstrukcję natury stanu sabaja, której dokonał Per Kvaerne, głównie na podstawie Tantry Hewadżry (Kvaerne, 2005: szczególnie 191-192).

${ }^{6}$ Zdaniem Wedemeyera był to krok nowatorski, powielony w tantryzmie śiwaickim (Wedemeyer, 2013: 166-167). 
Traktowanie manipulacji symbolami oraz rozwoju mądrości jako przeciwstawnych metod jest bezzasadne, jeśli zważyć na powszechną w wadżrajanie akceptację trzech poglądów. W ramach pierwszego uznawano możliwość swoistego rezonowania organizmu psychofizycznego w sytuacji poddania go wpływowi rzeczywistości doskonałej. Rezonans ów polega na zharmonizowaniu sposobu funkcjonowania adepta $\mathrm{z}$ aktywnością, która charakteryzuje stan buddy. Tej aktywności tradycyjnie przypisywano zaś aspekt poznawczy. Zgodnie z drugim przekonaniem, symbole stanu buddy mogą realnie uobecniać ten stan, co umożliwia jego oddziaływanie na adepta. Trzeci pogląd dotyczy ścisłej koordynacji różnych aspektów sposobu funkcjonowania organizmu psychofizycznego. Zgodnie z tym zapatrywaniem, zachodzą daleko idące oddziaływania między różnymi aspektami funkcjonowania organizmu adepta. Na gruncie wskazanych założeń akceptacja tezy o zależności cnót o charakterze kognitywnym od rytuałów (lub odpowiedniej manipulacji symbolami w wyobraźni) może być uznana za uzasadnioną.

Manipulacja symbolami i dążenie do mądrości są w wadżrajanie zwykle uważane za aspekty tego samego procesu, zaś stan buddy jest rozumiany jako synteza tak zwanych środków (praktyki) i mądrości. Traktowanie „środków” i mądrości jako czynników przeciwstawnych (świadczy o tym dobór symboli tych czynników) nie wyraża bynajmniej przekonania o antynomialności stanowiska łączącego manipulację symbolami z rozwojem mądrości. Jest raczej świadectwem sposobu rozumienia autentycznej mądrości jako stanu, który dramatycznie odbiega od standardowego sposobu funkcjonowania umysłu (także umysłu adepta, który metodycznie dąży do osiągnięcia stanu buddy).

Autorzy tantr nie przypisywali takiego znaczenia rozwojowi cnót moralnych, jak zwolennicy klasycznego ideału bodhisattwy. Trudno jednak mówić o otwartym odrzuceniu tradycyjnego buddyjskiego poglądu o potrzebie doskonalenia moralnego czy o jakimś zasadniczym konflikcie między tym poglądem a nowatorskimi technikami wadżrajany. Ignorowanie norm moralnych nie jest cechą charakterystyczną choćby tylko jej wczesnej postaci. Zwykle realna transgresja w stosunku do przyjętych norm zachowania (o ile w ogóle w danym środowisku występowała) miała charakter selektywny i sprowadzała się do kontekstów rytualnych. Christian Wedemeyer twierdzi, że uczestnictwo poszczególnych osób w rytualnych praktykach o charakterze „antynomiańskim” było zazwyczaj ograniczone w czasie (do sześciu miesięcy). W takich obrzędach uczestniczyła tylko elita adeptów o wyjątkowych, żmudnie osiąganych kwalifikacjach (Wedemeyer, 2013: 149-152). W późniejszej wadżrajanie zaleceń przekraczania norm zachowania zwykle nie interpretowano dosłownie, zaś w schematach religijnej praktyki wiele uwagi poświęcano rozwojowi cnót moralnych.

Tsuda sądzit, że wzorzec dążenia do moralnej doskonałości jest niezgodny $\mathrm{z}$ modelem soteriologicznym, który decyduje o specyfice tantrycznego 
buddyzmu7. Był bowiem przekonany, że w wadżrajanie „czystej” (konsekwentnej $\mathrm{w}$ traktowaniu kwestii soteriologicznych) manipulacja symbolami pełni rolę wystarczającego warunku wyzwolenia. Przekonania tego ewidentnie nie podzielało i nie podziela wielu wyznawców tantrycznego buddyzmu. Nawet we wczesnych fazach rozwoju wadżrajany skuteczność rytuału uzależniano od wszechstronnych kwalifikacji adepta (Wedemeyer, 2013: 149-152). Wiara w skuteczność rytualnych symboli nie wyklucza przecież przekonania, że owa skuteczność jest zależna od przymiotów osoby, która symbolami operuje. Nawet uznanie tego, że w wadżrajanie manipulacja symbolami jest czasem uważana za wystarczający warunek osiągnięcia stanu buddy, nie powinno prowadzić do akceptacji podejścia japońskiego badacza. Stanowisko soteriologiczne, które łączy wymóg manipulowania symbolami stanu buddy z wymaganiem rozwoju osobistych cnót, nie jest bowiem niespójne i nie musi być traktowane jako hybryda przeciwstawnych podejść.

Ad 3. Autorzy buddyjskich tantr zakładali wieloetapowość rozwoju adepta. Stanowi to świadectwo myślenia o praktyce religijnej w kategoriach procesu, który polega na osiąganiu i doskonaleniu określonych przymiotów. Przyjmowano przecież, że po przejściu rytualnej inicjacji niezbędne jest kontynuowanie osobistej praktyki. Inicjacja wyposażać ma adepta w kwalifikacje (niesprowadzalne do znajomości niezbędnego instruktażu) niezbędne do podjęcia samodzielnej praktyki, ale niewystarczające do osiągnięcia stanu buddy. W oderwaniu od gradualistycznego sposobu myślenia trudno wyjaśnić powszechną akceptację modelu inicjacji jako serii odrębnych obrzędów. O wymaganiach, które stawiano osobom rozpoczynającym rytualną praktykę o charakterze transgresyjnym, wspomniano wyżej. Jest rzeczą oczywistą, że wszędzie tam, gdzie ważną rolę odgrywają wyrafinowane techniki wizualizacyjne, niezbędny jest stopniowy rozwój odpowiednich umiejętności. To samo można powiedzieć o technikach manipulacji siłą życiową. Wydaje się, że zestawienie technik reprezentujących te dwie klasy prowadziło do wyróżnienia dwóch zasadniczych etapów rozwoju adepta $^{8}$.

Nie ulega wątpliwości, że uzyskanie przez adeptów wadżrajany przymiotów, które uznają oni za pożądane, może wymagać systematycznego wysiłku i długiego czasu. Traktowanie własnych praktyk religijnych jako niewymagających wysiłku i szybko prowadzących do oczekiwanych rezultatów (nie mówiąc już o skuteczności natychmiastowej) nie jest typowym podejściem zwolenników

${ }^{7}$ Charakteryzując naturę tantrycznej jogi, japoński badacz wskazywał na koncentrowanie się adepta na związku z wzorcową rzeczywistością oraz na lekceważenie więzi z innymi ludźmi, uwzględnianymi co najwyżej jako źródło ezoterycznego pouczenia lub jako współuczestnicy rytuałów (Tsuda, 2005: 419).

${ }^{8}$ Chodzi o fazy zwane utpanna-krama (utpatti-krama) oraz sampanna-krama (nispanna-krama). Por. np. Gray, 2007: 71-74. Więcej na ten temat niżej (Soteriologiczny paradygmat wadżrajany, pkt 9). 
tantrycznego buddyzmu. Przypisanie pewnym praktykom wadżrajany statusu łatwych było związane z tym, że nie wymagają one wyrzeczenia się zaspokajania potrzeb popędowych ${ }^{9}$. Poza tym tantryczne techniki zawsze mogą być uznane za łatwiejsze i prowadzące do celu szybciej niż techniki mahajany. Ów punkt odniesienia był bowiem postrzegany jako droga ekstremalnie trudna i wręcz niewyobrażalnie długotrwała. W tej sytuacji soteriologiczna atrakcyjność wadżrajany pozostaje niezagrożona, nawet jeśli od jej zwolenników wymaga się długotrwałego zaangażowania, systematycznego treningu czy codziennych wyrzeczeń.

Ad 4. Pogląd, zgodnie z którym metody stosowane $\mathrm{w}$ wadżrajanie są znacząco bardziej efektywne niż te zalecane w mahajanie, nie jest tożsamy z przekonaniem o powszechnej dostępności i uniwersalnej skuteczności tych technik. Przywołane wyżej wymaganie wyjątkowych kwalifikacji od uczestników obrzędów, w których przekraczane są powszechnie uznane normy zachowania, świadczy o elitarnym charakterze tego rodzaju rytuałów. Na ograniczoną dostępność różnych technik religijnych wskazują również inne fakty potwierdzone w tantrach: (1) uznawanie pewnych praktyk za sekretne, żądanie dyskrecji i przewidywanie najgorszych kar dla osób niedochowujących tajemnicy ${ }^{10}$; (2) stosowanie języka tajemnego (sandbya $\bar{a}-b h \bar{a} s \underline{a})^{11}$; (3) wysoce uciążliwy charakter pewnych praktyk, który $\mathrm{w}$ zasadzie uniemożliwiał ich łączenie $\mathrm{z}$ normalną świecką aktywnością ${ }^{12}$. Osobisty mistrz jest w wadżrajanie niezbędny jako aktywna manifestacja stanu buddy, która w kontekście rytualnym induku-

${ }^{9}$ Zalecano kurację „homeopatyczną” i sublimującą, która ma umożliwiać przemianę odpowiednio zaspokajanego popędu w jego przeciwieństwo. Zob. np. Tantra Hewadżry II.II.46-51 (Snellgrove, 1959b: 51).

${ }^{10}$ Dotyczy to również tantry Sarva-tathāgata-tattva-saṃraba (Yamada, 1981: 144-145).

${ }^{11}$ Interpretacja szczególnych aktów komunikacji, do których odnoszą się nazwy sandbyā-bhāṣā, sandhā-bhāssa, sandbyā bbāṣita itp., pozostaje kwestią sporną. Zgodnie z pierwszą wykładnią (np. David Snellgrove, Ronald Davidson) chodzi o akty posługiwania się językiem tajemnym, czyli systemem słów, którym przypisano (ściśle określone) znaczenia niejawne. Główną funkcją tego języka jest taki przekaz informacji, który wyklucza osoby niepowołane z kręgu odbiorców. Według zwolenników drugiego podejścia (Alex Wayman, George R. Elder), w grę wchodzi raczej „język półmroku”, którego wyrażenia są celowo naznaczone semantyczną nieokreślonością. Wyrażenia te odnoszą się do mistycznych stanów, ale czynią to w sposób, który uświadamiać ma adeptowi zarówno aktualną niedostępność i niezrozumiałość ich semantycznych korelatów, jak i zasadniczą bezradność myślenia pojęciowego w tym zakresie. Dzięki temu ,język półmroku” wprowadzałby aurę tajemniczości i wzmacniałby transgresyjną postawę adeptów (por. np. Elder, 2005: 61-70). Pierwsza wykładnia w oczywisty sposób wspiera tezę o elitarnym charakterze pewnych praktyk wadżrajany. Elder słusznie uznał, że zwolennicy drugiej interpretacji nie mogą zupełnie zignorować takich aktów komunikacji, które ukrywają treść wypowiedzi adeptów przed osobami niepowołanymi (Elder, 2005: 71-72).

${ }^{12}$ Wedemeyer wykazat, że praktyka zalecana w tantrach maha-jogi i tantrach jogini bardzo często obejmuje wędrowny i żebraczy tryb życia, czyli bezdomność (Wedemeyer, 2013: 138-139). Doskonałym przykładem takiego podejścia jest dziewiąty rozdział Tantry czaszki Buddy (Wedemeyer, 2013: 209-210). 
je w adepcie, wespół z innymi symbolami, obecność pożądanych właściwości. Mistrz jest depozytariuszem pewnej tradycji oraz nauczycielem, który dzięki własnemu doświadczeniu jest zdolny do przedłożenia odpowiednich wyjaśnień i do korygowania postępowania ucznia. W kontekście przywołanych faktów trudno nie uznać, że już w okresie powstawania buddyjskich tantr mistrzowi przypisywano również rolę osoby, która dokonuje selekcji kandydatów do inicjacji (Snellgrove, 2002: 176-180).

W literaturze komentatorsko-apologetycznej obecny jest pogląd, zgodnie z którym tantryczna praktyka jest odpowiednia wyłącznie dla osób o najwyższych kwalifikacjach ${ }^{13}$. W usystematyzowanej wadżrajanie ważniejszą rolę odgrywa jednak stanowisko bardziej umiarkowane, zgodnie z którym elitarny charakter mają tylko określone techniki tantryczne. Taki punkt widzenia jest naturalny tam, gdzie mamy do czynienia z praktyką religijną rozumianą jako wielostopniowa i mniej czy bardziej uciążliwa. Nie ma powodów, by interpretując tantryczny buddyzm, uznawać za wzorcowy pogląd o powszechnej dostępności i uniwersalnej skuteczności technik zbawczych, zaś w odmiennych stanowiskach widzieć „zgniły” (naznaczony brakiem konsekwencji) kompromis z mahajaną. Rozpowszechniony w wadżrajanie sposób rozumienia praktyki religijnej jako procesu, który ma charakter żmudny, długotrwały i (szczególnie $\mathrm{w}$ jego zaawansowanych fazach) elitarny, pozostaje w zgodzie z tym poglądem, którego akceptacja rzeczywiście wydaje się decydować o specyfice wadżrajany. Mam na myśli przekonanie o konieczności posłużenia się symbolami stanu buddy.

\section{SOTERIOLOGICZNY PARADYGMAT WADŻRAJANY}

Powyższe rozważania pozwalają odrzucić tezę Tsudy, zgodnie z którą wadżrajana stanowi ruch rozdarty między dwoma niemożliwymi do pogodzenia modelami soteriologicznymi. Podejście uznawane za niezborne wcale takim nie jest. Pokusić się można o zdefiniowanie wewnętrznie spójnego modelu soteriologicznego, który jest charakterystyczny dla całego buddyzmu tantrycznego.

Soteriologiczny model wadżrajany dzieli ze starszymi postaciami buddyzmu pryncypia sposobu rozumienia ludzkiej egzystencji. Wspólna jest również wiara w możliwość transformacji tej egzystencji do stanu buddy. Istota, która taki stan osiągnęła, uzyskuje jakoby niezależność od zasad rządzących światem oraz ostatecznie uwalnia się od cierpienia. Szczególne w przypadku buddyzmu tantrycznego jest natomiast przekonanie, że do osiągnięcia stanu buddy niezbędne jest odpowiednie wykorzystanie symboli tego stanu. Manipulacja symbolami stanu buddy jest przy tym uznawana za aktywność:

${ }^{13}$ Por. np. poglądy Tripitakamali czy Sahadżawadżry (Onians, 2002: 132-135, 144-145). 
1. umożliwiającą ostateczną transformację osobowości adepta (a nie tylko osiąganie pośrednich stopni duchowego rozwoju);

2. skuteczną niezależnie od woli istot różnych od adepta (dzięki czemu jest on przekonany o sprawowaniu kontroli nad procesem swej zbawczej przemiany) ${ }^{14}$.

Myśląc o wadżrajanie jako o formacji historycznej (a nie o abstrakcyjnie traktowanym modelu soteriologicznym), należy oczywiście uwzględniać określony, historycznie uwarunkowany dobór symboli stanu buddy. Wśród nich ważną rolę odgrywają wizerunki istot oświeconych i mandale, mantry, mudry, motywy seksualne (szczególnie coitus oraz mieszanina nasienia i żeńskiej wydzieliny płciowej, jako symbole syntezy przeciwieństw lub przekroczenia ograniczeń poznania dychotomizującego, a także męskie nasienie), topos transgresji (łamanie norm zachowania jako symbol mądrości, która charakteryzuje się nieobecnością dychotomicznych schematów poznawczych, między innymi emocjonalnie angażującego schematu „czyste-nieczyste”), wadżra i dzwonek.

Wydaje się, że zaproponowany właśnie sposób rozumienia modelu soteriologicznego w tantrycznym buddyzmie pozwala przezwyciężyć problem rozmytości pojęcia wadżrajany. By uniknąć zniekształcania sensu przedstawionej propozycji (wskutek nadmiernych uproszczeń lub ignorowania występujących zróżnicowań), niezbędne jest uwzględnienie następujących faktów:

1. Zaproponowany przez Davida Snellgrove'a przekład fragmentu Tantry Hewadżry, zgodnie z którym wyłącznie praktyka zalecana w tym tekście jest soteriologicznie skuteczna, należy uznać za błędny (Onians, 2002: 158-159) ${ }^{15}$. W wadżrajanie ścierały się różne opinie na temat wartości innych buddyjskich tradycji soteriologicznych. Zgodnie z rozpowszechnionym poglądem tradycyjne sposoby realizacji stanu buddy nie są nieskuteczne z zasady. Deprecjonowano je jednak jako skrajnie uciążliwe lub ekstremalnie długotrwałe. Traktowanie manipulacji symbolami jako koniecznego warunku wyzwolenia może więc mieć charakter ograniczony do kontekstu, w którym pod uwagę brane są realne możliwości adeptów lub akceptowalny horyzont czasowy.

2. W podstawowej wersji soteriologicznego modelu wadżrajany przyjmuje się, że stan buddy (rozumiany jako rzeczywistość doskonała) jest za pomocą symboli realnie uobecniany i wywiera bezpośredni wpływ na psychofizyczny organizm adepta. Dzięki temu rzeczywistość doskonała może funkcjonować w ramach religijnej praktyki zarówno jako wzorzec, jak i jako czynnik kształtujący. Istnieje jednak również psychologistyczny wariant rozpatrywanego modelu,

\footnotetext{
${ }^{14}$ Abstrahuję tu od roli osobistego mistrza, który wprowadza adepta w tajniki praktyki tantrycznej.

${ }^{15}$ Chodzi o fragment I.VIII.55 (Snellgrove, 1959a: 78). Isabelle Onians dokonała przeglądu stanowisk komentatorów tantr w sprawie wyższości metod wadżrajany (Onians, 2002: 86-160).
} 
w którym symbolom przypisywana jest skromniejsza rola tematów uwagi katalizujących procesy psychiczne kulminujące w osiągnięciu stanu buddy ${ }^{16}$.

3. W wadżrajanie przyjmuje się, że manipulacja symbolami może doprowadzić adepta do stanu, który ściśle odpowiada rzeczywistości wzorcowej (semantycznemu korelatowi symboli). Za pomocą symboli rzeczywistości doskonałej adept ma być wprowadzany w stan swoistego rezonansu, który „dostraja” aktywność organizmu do rzeczywistości wzorcowej. Wiara w zachodzenie takiego rezonansu często znajduje uzasadnienie w przekonaniu o takożsamości adepta $\mathrm{i}$ istot oświeconych na poziomie ich ukrytej natury (rozumianej w duchu koncepcji natury buddy). W takim wypadku rezonans ma sprawiać, że wspólna natura odgrywa w obrębie psychofizycznego organizmu adepta rolę, która odpowiada funkcji pełnionej przez nią w organizmie buddy. Często występuje również przekonanie o istnieniu strukturalnej odpowiedniości między rzeczywistością wzorcową i organizmem adepta. Rezonans ma wtedy korygować sposób działania poszczególnych części organizmu, umożliwiając przejście odpowiedniości strukturalnej w odpowiedniość funkcjonalną ${ }^{17}$.

4. Koncepcja zbawczego rezonansu łączy się z przekonaniem, że stan buddy stanowi zwieńczenie odpowiednio ukierunkowanego wysitku adepta. Celem tego wysiłku jest przekształcenie własnej osoby w określony sposób. W tej sytuacji postawa adepta musi w szczególny sposób łączyć aktywność z biernością. Adept musi poddać się wpływowi rzeczywistości doskonałej rozumianej jako czynnik zewnętrzny. Wpisane jest to jednak w ramy procesu przekształcania siebie do stanu doskonałości. Symbole są soteriologicznie skuteczne w kontekście właściwego wysiłku adepta. Brak wysiłku byłby tożsamy z ignorowaniem pryncypiów buddyjskiej tradycji. Wiele wykorzystywanych w praktyce symboli to zarówno media, przez które ma działać rzeczywistość doskonała, jak i znaki kierujące uwagę adeptów ku określonemu ideałowi egzystencji i mobilizujące do realizacji tego ideału. W taki sposób funkcjonują wizerunki oświeconych istot, do których adept stara się upodobnić.

5. Zgodnie z buddyjską tradycją ważnym, a nawet kluczowym, aspektem procesu doskonalenia własnej osoby jest zmiana sposobu rozumienia samego siebie. Za warunek osiągnięcia stanu buddy uznawano usunięcie błędu, który polega na niewłaściwej interpretacji własnego statusu bytowego. Indyjska

${ }^{16}$ Wariant psychologistyczny wydaje się pozostawać w związku z akceptacją określonego stanowiska ontologicznego, która decyduje o sposobie rozumienia bóstw jako wytwarzanych przez świadomość adepta. Por. uwagi Joanny Greli na temat statusu bóstw według zwolenników stanowiska rangtong (Grela, 2005: 104-106).

${ }_{17}$ Tak na przykład w Tantrze powstania najwyższej przyjemności odpowiednim częściom ciała, w których lokalizowano szlaki przepływu życiowej energii, przyporządkowano miejsca stanowiące cel pielgrzymek (geograficzne lokalizacje bóstw) oraz cnoty bodhisattwy. Same szlaki przepływu energii zestawiono zaś z poszczególnymi postaciami mandali, tj. wzorcowej społeczności istot oświeconych. Zob. Samvarodaya-tantra VII.1-15, IX.12-25 (Tsuda, 1974: 93-96, 104-105) i Vajradāka-tantra XIV.14-30 (Tsuda, 2015: 467-469). 
wadżrajana przejęła ten sposób myślenia, poddając go jednak modyfikacji. Ważną rolę przyznano technikom opartym na wizualizacji i autosugestii, które są traktowane jako metody rozwoju niezachwianego przekonania o takożsamości własnej osoby i rzeczywistości wzorcowej. Rozpatrywany w tej perspektywie symbol stanu buddy (na przykład wizerunek istoty oświeconej) nie tylko funkcjonuje jako nośnik obiektywnej mocy (pkt 3), nie tylko reprezentuje określony ideał egzystencji (pkt 4), ale również stanowi punkt odniesienia (swego rodzaju matrycę) w procesie kształtowania posiadanego obrazu własnej osoby na drodze autosugestii ${ }^{18}$.

6. Manipulacja symbolami ma charakter rytualny lub dokonuje się w wyobraźni. W wypadku realizacji trzeciej z funkcji przypisywanych symbolom stanu buddy (pkt 5), obiektom materialnym przypada rola pomocnicza. Zwykle występują mieszane formy praktyki. Dotyczy to również psychologistycznego wariantu wadżrajany, bowiem jego zwolennicy uważają zmysłowo daną obecność symboli za pomocną.

7. Stanowi buddy tradycyjnie przypisywano aspekt poznawczy, utożsamiając go z mądrością. Mądrość tę rozumiano jako efekt bezpośredniego poznania natury rzeczywistości. Buddyjską filozofię traktowano zwykle jako próbę eksplikacji mądrości buddów. Buddyzm tantryczny przejął te przekonania. Pozwoliło to przedstawicielom wadżrajany pozytywnie oceniać wartość buddyjskiej filozofii i wykorzystać jej dokonania do systematycznej interpretacji tantr. W ramach tej interpretacji uwzględniono dokonania z zakresu ontologii, filozofii umysłu, psychologii i prakseologii medytacji. Tym samym wiele kontrowersji charakterystycznych dla starszej myśli buddyjskiej zostało przeniesionych na grunt buddyzmu tantrycznego ${ }^{19}$.

8. Indyjscy buddyści pozostawali w rozmaitych związkach $\mathrm{z}$ wyznawcami innych religii. Niebuddyjskie tradycje bez wątpienia wywarły wpływ na postać rytuałów i treść wizualizacji w wadżrajanie ${ }^{20}$. Wpływały na dobór symboli, co stanowiło jeden z czynników odpowiedzialnych za różnorodność tantrycznego buddyzmu. Nie ma jednak powodów, by soteriologiczny model wadżrajany wyprowadzać ze źródeł pozabuddyjskich. Akceptacja tego modelu stanowi realizację możliwości, którą stworzył sposób rozumienia świata typowy dla mahajany. Zgodnie z tym światopoglądem, uniwersum jest pełne istot oświeconych, które zamieszkują niebiańskie dziedziny, są wyposażone w cudowne moce i w rozmaity sposób pomagają ludziom. Przyjmowano, że dzięki rytuałom i wizualizacji można nawiązać $\mathrm{z}$ nimi bezpośredni kontakt. W charakterystycznym dla

${ }^{18}$ To właśnie identyfikacja z określoną istotą oświeconą jest naturą tak zwanej jogi bóstwa. Zdaniem Jacoba Daltona taki sposób rozumienia praktyki pojawił się w tak zwanych tantrach jogi (por. pkt 9).

${ }_{19}$ Przykładem może być spór między zwolennikami filozofii madhjamaki oraz zwolennikami koncepcji natury buddy w wadżrajanie tybetańskiej (np. Williams, 2000: 134-138).

${ }^{20}$ Skala i źródło tych zapożyczeń pozostają kwestiami spornymi. 
wadżrajany przekonaniu o soteriologicznej skuteczności symboli stanu buddy można widzieć rezultat stosunkowo nieznacznej zmiany tego podejścia. Zmianę tę można wiązać z rozpowszechnioną w mahajanie koncepcją nieosobowego ciała dharmicznego (dbarma-kāya) buddy. W dojrzałym wariancie tej koncepcji przyjmuje się, że stan buddy jest wszechobecnym wymiarem rzeczywistości. Wiara zwolenników wadżrajany w funkcjonalną tożsamość istoty oświeconej oraz rytualnych symboli, rozpatrywana w kontekście tego stanowiska, nie musi być traktowana jako bunt przeciw pryncypiom buddyjskiej tradycji. W tradycji natury buddy (tathagāta-garbha) przyjmowano zaś, że stan buddy stanowi aktualny, chociaż ukryty, składnik każdej świadomej istoty. Rozwój tej koncepcji zdaje się sprzyjać akceptacji poglądu o zbawczym rezonansie, który rzeczywistość doskonała wzbudza w organizmie adepta.

Kult relikwii, wizerunków istot oświeconych i świętych tekstów odgrywał w indyjskim buddyzmie ważną rolę na długo przed rozwojem wadżrajany. W mahajanie uznawano, że dzięki rytuałom i wizualizacji granica między codzienną rzeczywistością a dziedziną istot oświeconych może zostać doraźnie zniesiona. Przejście do modelu tantrycznego można rozumieć jako przekształcenie buddyjskiej praktyki w duchu poglądu, który symbolom rzeczywistości doskonałej przypisuje zdolność transformowania adepta do stanu buddy. Ów pogląd nie wyklucza przyznania ważnej roli cnotom poznawczym i moralnym, które tradycyjnie uznawano za wystarczające warunki wyzwolenia. W tej perspektywie powstanie wadżrajany oraz związana z tym zmiana modeli soteriologicznych nie prezentują się tak dramatycznie, jak w ujęciu Tsudy. Nacisk można położyć na ciągłość z tradycją i fascynację możliwościami wykreowanymi w obrębie starszego systemu przekonań. Nawet jeśli inspiracją dla rozwoju nowego paradygmatu był sposób rozumienia rytuałów poza buddyzmem, to rozwój ów został przygotowany przez odpowiednie procesy wewnętrzne. Wydaje się, że o atrakcyjności nowego podejścia, czyli nowych (rytualnych) technik, decydowały cechy takie, jak „konkretność” (możliwość położenia nacisku na czynniki zewnętrzne, a nie na psychologiczne subtelności), zdolność wzbudzania intensywnych emocji, zgodność z pozabuddyjskimi trendami oraz użyteczność w stosunkach z polityczną władzą.

9. Jacob Dalton próbował określić schemat rozwoju rytuału w indyjskim buddyzmie tantrycznym ${ }^{21}$. W jego przekonaniu czynnikiem decydującym o oryginalności obrzędów dojrzałej wadżrajany jest dążenie do internalizacji starszych postaci buddyjskiego kultu. Polegały one na oddawaniu czci istotom oświeconym uważanym za różne od adepta (i reprezentowanym przez fizyczny wizerunek/symbol czy wyobrażony obraz). W taki sposób autorzy wczesnych

${ }^{21}$ Dalton uwzględnił tybetańskie manuskrypty odkryte w Dunhuang (powstałe między późnym wiekiem VIII a wiekiem X). Widzi w ich analizie jeden z kluczy do rekonstrukcji rozwoju wczesnej wadżrajany (Dalton, 2004: 2-4). 
podręczników praktyki wadżrajany oraz twórcy komentarzy do tantr rozumieli status rytuałów $\mathrm{w}$ tak zwanych tantrach działania (kriya-tantra), przeciwstawiając je tak zwanym tantrom jogi (yoga-tantra). W tych drugich dokonać się miał zwrot, który polegał na uznaniu samego siebie za tożsamego z głównym obiektem kultu (zwykle ulokowanym w środku mandali) ${ }^{22}$. Zwrot ten stanowiłby początek buddyjskiej jogi bóstwa, która polega na dążeniu do pełnej identyfikacji własnej osoby z określoną istotą oświeconą.

Autorzy analizowanych przez Daltona tantr jogi zalecają wizualizowanie siebie jako buddy i składanie sobie ofiar. Jednym z kluczowych zespołów kategorii, które w tych tekstach wykorzystano do opisu przemiany adepta, są pojęcia mudr. Mudry stanowią cztery płaszczyzny identyfikowania się adepta z adorowaną istotą oświeconą. Pierwsza płaszczyzna (mabā-mudrā) obejmuje wygląd, druga (dharma-mudrā) — wypowiedzi, trzecia (samaya-mudrā) — ozdoby (jak kwiat lotosu czy wadżra) rozumiane jako symbole cnót, czwarta zaś (karma$-m u d r \bar{a})$ - pozy i działania. Stosownie do tego adept w wyobraźni jednoczy ciało istoty oświeconej z własnym, wizualizuje mantrę w swoim w sercu, zdobi się oraz przyjmuje ofiary ${ }^{23}$. O ile $\mathrm{w}$ systemach związanych z tantrami działania kluczowe jest składanie ofiar rozumianych tradycyjnie (jako aktywność zewnętrzna), to w tantrach jogi ofiara uzyskuje status czynności, która dokonuje się w wyobraźni. Obrzędy tradycyjne zostały zachowane, ale często jako techniki pomocnicze. Samodzielną praktykę poprzedzała inicjacja, w rezultacie której adept podlegał wstępnej przemianie, stając się miejscem odpowiednim do zamieszkania przez adorowaną istotę doskonałą (Dalton, 2004: 5-7).

Zdaniem Daltona kolejnemu etapowi rozwoju sposobu, w jaki rozumiano rytuały w wadżrajanie, dają świadectwo wczesne (z drugiej połowy VIII wieku i początku IX wieku) teksty z grupy tak zwanych tantr wielkiej jogi (mabā-yoga-tantra). Etap ten charakteryzować się ma szczególnym zainteresowaniem adeptów własnym ciałem. Wyróżniono wtedy dwie fazy praktyki. W ramach fazy rozwoju (utpanna-krama) adept doskonalit umiejętność wizualizowania mandali z własną osobą w centrum. Wizualizacja rozpoczynała się od kontemplacji pustki (śünyatā) i rozwijała się według określonych zasad. Radykalnie nowatorską technikę wprowadzono w ramach fazy spełnienia (sampanna-krama). Była to obrzędowa praktyka seksualna kulminująca w coitus reservatus. Odczuwanie w tym stanie rozkoszy miało prowadzić do spontanicznego wytworzenia wizji mandali (w fazie rozwoju mandalę wizualizowano mozolnie). Seksualną rozkosz, która przenika ciało adepta, rozumiano jako najwyższą postać siły życiowej i moc ożywiającą mandalę. Odczuwanie rozkoszy traktowano jako sposób oddawania czci istotom oświeconym. Jej kwintesencją jest

\footnotetext{
${ }^{22}$ Jako najbardziej wpływową z ta nt r jog i Dalton wskazał tantrę Sarva-tathāgata-tattva-saingraba z pierwszej połowy VIII wieku (ostateczny kształt tekst uzyskał zapewne w drugiej połowie tego stulecia).

${ }^{23} \mathrm{~W}$ późniejszych tantrach mudry rozumiano inaczej (Kvaerne, 2005: 183-190).
} 
kropla spermy, która stanowi symbol stanu buddy i zarazem ofiarny dar. Dalton przypuszcza, że początkowo obrzęd kulminował w spożyciu przez adepta swego nasienia (pochodzącego z waginy partnerki), co stanowiło najwyższy sakrament i formę samouświęcenia. To wszystko prowadzić miało do zaniku wizualizowanej mandali i pogrążenia się umysłu adepta w stanie braku manifestacji jakichkolwiek zróżnicowań (Dalton, 2004: 7-21).

Dalton sądzi, że w IX wieku z tej stosunkowo prostej koncepcji rozwinęły się skomplikowane systemy mistycznej quasi-fizjologii znane z tekstów, które w większości zaliczono do kategorii tantr najwyższej jogi (anuttara-yoga-tantra). W owych systemach wyróżniano wiele kanałów i ośrodków życiodajnej mocy oraz postulowano stosowanie wyszukanych technik kontroli sposobu, w jaki moc przemieszcza się w ciele. Miało to prowadzić do osiągnięcia stanu buddy albo przynajmniej do antycypacji tego stanu. Tego rodzaju techniki miały zdominować fazę spełnienia po X wieku. Początkowo były osadzone w kontekście rytuatów seksualnych, lecz później się usamodzielniły. Towarzyszyło temu sprowadzanie motywów seksualnych do rangi symboli quasi-fizjologicznych procesów, do tematów wizualizowanych w wyobraźni lub do ikonograficznego sztafażu. Ten proces sprzyjał pogłębianiu syntezy nowych technik oraz tradycji mahajany. Dalton skłania się do przekonania, że tak zwana inicjacja sekretu (gubya-abbişeka), która stała się w późniejszym okresie trzecią w standardowej serii czterech inicjacji (inicjowany spożywa w jej trakcie nasienie mistrza), rozwinęła się z opisanej wyżej pierwotnej postaci fazy spełnienia. Spożywanie własnego nasienia zostałoby z praktyki usunięte (Dalton, 2004: $21-26)^{24}$.

\section{ZAKOŃCZENIE}

Celem przedstawionego tekstu jest identyfikacja soteriologicznego paradygmatu, którego akceptacja łączy różnorodne tradycje zaliczane do tantrycznego buddyzmu. Realizacja takiego zadania pozwoliłaby przezwyciężyć rozmytość pojęcia wadżrajany. Jako charakterystyczne dla rozpatrywanego paradygmatu wskazano wyżej przekonanie, że niezbędne do osiągnięcia stanu buddy jest posłużenie się jego symbolami. Odpowiednia manipulacja nimi ma charakter rytualny lub dokonuje się w wyobraźni adepta. Adept jest przy tym przeświadczony, że owa manipulacja umożliwia mu osiągnięcie celu ostatecznego (a nie wyłącznie celów pośrednich) oraz że za pośrednictwem symboli uruchamia i kontroluje procesy, które zachodzą niezależnie od woli istot oświeconych. Taka postawa adepta nie

\footnotetext{
${ }^{24}$ Celem autora niniejszego tekstu nie jest ocena adekwatności diachronicznego schematu zaproponowanego przez Daltona. Z punktu widzenia autora sprawą zasadniczą jest to, że znajomość tego schematu pozwala ustrzec się przed zawężonym sposobem rozumienia funkcji, jaką pełni manipulacja symbolami w wadżrajanie.
} 
wyklucza przyznania ważnej roli cnotom poznawczym i moralnym. Opisane soteriologiczne stanowisko wydaje się odbiegać od sposobu myślenia przedstawicieli wszystkich innych odłamów buddyzmu. Krótko omówiono główne warianty tego stanowiska oraz podjęto próbę wykluczenia niewłaściwych (zakresowo zbyt wąskich) jego interpretacji.

Przedstawiona rekonstrukcja soteriologicznego paradygmatu wadżrajany powinna być traktowana jako propozycja, którą poddano wstępnej weryfikacji. Wymaga ona systematycznej konfrontacji ze źródłowymi tekstami i materiałem empirycznym. Trudno wykluczyć, że dokonana rekonstrukcja okaże się użyteczna jako podstawa typologicznego, a nie klasyfikacyjnego pojęcia tantrycznego buddyzmu.

\section{BIBLIOGRAFIA}

Dalton, J. (2004). The development of perfection: The interiorization of Buddhist ritual in the eighth and ninth centuries. Journal of Indian Pbilosopby, 32, 1-30.

Elder, G. R. (2005). Problems of language in Buddhist Tantra (s. 58-74). W: P. Williams (Red.). Buddhism: Critical concepts in religious studies (t. 6). London-New York: Routledge.

Gray, G. G. (2007). The 'Cakrasamvara tantra' (the discourse of Śrī Heruka). A study and annotated translation. New York: The American Institute of Buddhist Studies at Columbia University in New York.

Grela, J. (2005). Mabakala. Sześcioręki strażnik w buddyzmie tybetańskim. Kraków: Universitas. Kvaerne, P. (2005). On the concept of sahaja in Indian Buddhist Tantric literature (s. 162-208). W: P. Williams (Red.). Buddhism: Critical concepts in religious studies (t. 6). London-New York: Routledge.

Onians, I. (2002). Tantric Buddhist apologetics or antinomianism as a norm. Oxford: Oxford University. (Niepublikowana praca doktorska).

Snellgrove, D. (2002). Indo-Tibetan Buddhism: Indian Buddhists and their Tibetan successors. Boston: Shambhala Publications. [Wyd. 1: 1987].

Snellgrove, D. L. (1959a). The Hevajra Tantra. A critical study (cz. 1: Introduction and translation). London: Oxford University Press.

Snellgrove, D. L. (Red.) (1959b). The Hevajra Tantra. A critical study. (cz. 2: Sanskrit and Tibetan texts). London: Oxford University Press.

Tsuda, S. (Red.). (1974). The Samvarodaya-tantra. Selected chapters. Tokyo: The Hokuseido Press.

Tsuda, S. (2005). A critical Tantrism (s. 418-480). W: P. Williams (Red.). Buddhism: Critical concepts in religious studies (t. 6). London-New York: Routledge.

Wedemeyer, Ch. (2013). Making sense of Tantric Buddbism: History, semiology \& transgression in the Indian traditions. New York: Columbia University Press.

Williams, P. (2002). Buddyzm mabajana. (Tłum. H. Smagacz). Kraków: Wydawnictwo A.

Yamada, I. (Red.). (1981). Sarva-tathāgata-tattva-saingraha nāma mabāyāna-sūtra. A critical edition based on a Sanskrit manuscript and Chinese and Tibetan translations (=Sata-Pițaka Series, 262). New Delhi: Jayyed Press. 